\title{
Memberdayakan Peran Badan Arbitrase Syariah Nasional (BASYARNAS) dalam Penyelesaian Sengketa Ekonomi Syariah di Luar Pengadilan
}

\author{
Oleh: Sufriadi*
}

\begin{abstract}
Naturally, in community will have been conflict at the time. Especially for the development of the life. Such as in money transaction (economy) that have to need vertical development. In Indonesia, the development of syariah economy is growing up in golden era, while the condition of Basyarnas (Badan Arbitrase Syariah Nasional) - wich is one medium in legal action solving of non-litigation syaria economy - is declining. Its ineffective working is shown at the starting of syaria economy till growing up. This paper discribes the development of syaria economy and its rationalization needs with Basyarnas as alternative in legal action solving effectively for syaria economy practitioner. The one of solutions is a revision of Basyarna Regulations.
\end{abstract}

Keywords: Basyarnas, Penyelesaian Sengketa, Ekonomi Syariah

\section{Pendahuluan}

Kehadiran sistem perekonomian syariah Indonesia dalam kurun waktu dua dasawarsa terakhir berkembang sangat pesat. Hal tersebut terlihat bukan hanya dalam lingkungan perbankan saja, melainkan juga tumbuh dalam berbagai bidang bisnis yang lain, seperti asuransi syariah, pegadaian syariah, pasar modal syariah, dan yang lain. Dengan penunjukkan data-data dari banyak sumber tentang perkembangan ekonomi syariah, sehingga mengukuhkan pendapat banyak kalangan, terutama akademisi dan ekonom muslim, bahwa saat ini tidak ada

* Masiswa Program Dual Degree Jurusan Syariah FIAI dengan Jurusan Ilmu Hukum FH UII. Saat ini aktif di Lembaga Pers Mahasiswa Pilar Demokrasi Fakultas Ilmu Agama Islam UII; dan Ikatan Mahasiswa dan Keluarga Aceh Tenggara (IKAMARA) Yogyakarta 
Sufriadi: Memberdayakan Peran Badan Arbitrase Syariah Nasional ...

alasan untuk menolak penerapan sistem ekonomi syariah, khususnya Indonesia. ${ }^{1}$ Data lain mengenai efektifitas penerapan sistem ini dalam mengentaskan permasalahan-permasalahan ketimpangan di masyarakat juga menunjukkan hasil yang tidak dapat dikatakan menyedihkan. Salah satu wacana yang saat ini kerap didengungkan bahwa perkembangan ekonomi syariah adalah pengentas berbagai persoalan sosial seperti kemiskinan dan pengangguran. Sejatinya, hal semacam ini didukung oleh semua pihak dengan ikut berpartisipasi memperbaiki implementasi sistem ekonomi syariah dapat lebih berkembang.

Seiring dengan berkembangnya sistem perekonomian syariah dan diikuti dengan munculnya banyak perusahaan bisnis yang memproklamirkan diri menggunakan sistem syariah, maka berbagai konsekuensi natural pasti akan mengekor di belakang. Karena apapun ceritanya, ekonomi syariah juga masuk dalam kategori dunia bisnis, dimana pelaku bisnis satu akan betul-betul dihadapkan dengan persaingan seketat-ketatnya dengan pebisnis lain untuk meraih konsumen dan keuntungan. Pendek kata, dunia bisnis yang merupakan salah satu elemen yang berperan penting dalam pengembangan bangsa, selain pula menjadi dunia empuk bagi setiap orang mencapai finansial (penghasilan) lebih, tentu mendapat tantangan sangat terasa dibanding bidang lain. Oleh karena itu. pelaku bisnis selalu dituntut memantau dan memberi pertimbangan lebih dalam menjaga reputasi dan kredibilitasnya di depan konsumen dan khalayak masyarakat. Karena di balik semua itu, tantangan industri perbisnisan juga pasti dihadapkan dengan berbagai persoalan substansi terkait dengan berbagai resiko, seperti kehilangan reputasi akibat sengketa dengan konsumen yang tidak diselesaikan dengan cara terbaik dan up to date.

Terkait hal ini, Suyud Margono menyatakan bahwa dengan maraknya kegiatan bisnis (termasuk ekonomi syariah, pen), tidak mungkin dihindari terjadinya sengketa (disputeldifference) antara pihak yang terlibat, baik antara pelaku bisnis (perusahaan) satu dengan pelaku bisnis (perusahaan) yang lain, atau pelaku bisnis (perusahaan) dengan konsumennya. ${ }^{2}$ Untuk menjawab persoalan mendasar ini, para pelaku bisnis dan para pakar harus mencari model penyelesaian sengketa yang efektif dan efisien untuk menghadapi kegiatan bisnis yang free market and free competition. Dengan kata lain, harus ada satu lembaga

${ }^{1}$ Mengenai perkembangan ekonomi syariah, baca dalam Nur Kholis (2006), Penegakan Syariah Islam di Indonesia (Perspektif Ekonomi), dalam Jurnal Hukum Islam Al Mawarid, Edisi: XVI, Fakultas Ilmu Agama Islam, Universitas Islam Indonesia, Yogyakarta, hal: 169-175. Adapun data lengkap tentang perkembangan ekonomi syariah dalam angka, lihat Dadang Muljawan (2007), Islamic Financial Engineering; A Regulatory Perspective, Slide yang disampaikan pada International Seminar on Islamic Financial Engineering 9-10 January, Yogyakarta, Indonesia. Atau lihat dalam http: // www.bi.go.id

2 Suyud Margono (2004), Alternative Dispute Resulotion (ADR) dan Arbitrase, (Bogor: Ghalia Indonesia), hal: Kata Pengantar 
khusus yang betul-betul dapat diterima dunia bisnis tertentu dan memiliki sistem penyelesaian sengketa dengan mudah, cepat dan biaya murah (quick and lower in time and money to the parties), serta (yang lebih penting) mampu menjaga reputasi pelaku bisnis itu.

\section{Realitas Lembaga Peradilan Indonesia dalam Penyelesaian Sengketa}

Cara penyelesaian konflik (sengketa) antar individu masyarakat (baca: perkara perdata) selama ini, cenderung lebih banyak dilakukan melalui jalur konvensional, yaitu penyelesaian perkara melalui jalur litigasi (pengadilan). Secara teoritis, lembaga peradilan diyakini dapat menunjukkan peran terbaiknya sebagai penekan berbagai pelanggaran hukum oleh elemen apa saja di sebuah negara, dan tempat akhir pencarian keadilan bagi pihak yang berperkara. Walaupun dalam perjalanannya dirasakan bahwa penyelesaian konflik melalui jalur ini kerap menimbulkan kesan kurang baik bagi para pihak. Dikatakan demikian, karena untuk mencapai keputusan final dari satu lembaga pengadilan, para pihak bersengketa memang dituntut untuk benar-benar bertarung di dewan hakim, sehingga akan ditentukan siapa yang menjadi pemenang 'pertandingan'. Adapun yang memiliki kedudukan yang lebih tinggi atau dominan, umumnya (dengan berbagai faktor yang ada) cenderung dimenangkan.

Selain itu, pengalaman pahit yang menimpa masyarakat hingga saat ini, mempertontonkan sistem peradilan yang tidak efektif (ineffective) dan tidak efisien (inefficient). Penyelesaian perkara memakan waktu puluhan tahun. Proses berteletele, yang dililit lingkaran hukum yang tidak berujung. Mulai dari banding, kasasi, dan peninjauan kembali. Setelah putusan berkekuatan hukum tetap, eksekusi dibenturkan lagi dengan upaya verzet dalam bentuk partai verzet dan derden verzet. Memasuki gelanggang forum pengadilan, tak ubahnya mengadu nasib di hutan belantara (adventure unto the unknown). Padahal, masyarakat pencari keadilan membutuhkan proses penyelesaian yang cepat yang tidak formalistis atau informal porocedure and can be put into motion quickly. ${ }^{3}$ Dengan demikian, asas yang seharusnya dilaksanakan dengan baik dan tertib (karena telah terumuskan dengan rapi dalam aturan formal) di setiap lembaga peradilan, tentu ternodai. Terlebih jika dikaitkan kembali dengan banyaknya konspirasi di pengadilan dan berbagai permasalahan lainnya yang memiliki potensi lebih, mengikuti. Akibatnya, kesan yang timbul dari lembaga peradilan tidak lagi sesuai dengan tujuan mulianya sebagai tempat pencari keadilan dengan dasar-dasar yang telah ditentukan. ${ }^{4}$

${ }^{3}$ M. Yahya Harahap (1997), Beberapa Tinjauan Mengenai Sistem Peradilan dan Penyelesaian Sengketa, (Jakarta: Sinar Grafika), hlm. 248.

${ }^{4}$ Baca lebih lengkap dalam Sudikno Mertokusumo (1998), Hukum Acara Perdata 
Ketidakmampuan ini, pada akhirnya mengakumulasi berbagai kelemahan lembaga peradilan yang telah tersebar luas ke segala penjuru masyarakat nusantara. Saat ini, kita sudah tidak dapat memilah pengadilan mana yang lebih parah, karena fenomena seperti ini telah menyebar ke seluruh lingkungan pengadilan, termasuk Pengadilan Agama. Asas-asas yang seharusnya dijalankan dengan efektif ternyata tercoreng dengan realita yang ada. Penyelesaian sengketa berjalan lambat, biaya perkara yang mahal, putusan pengadilan yang membingungkan, kemampuan para hakim bercorak generalis, dan lainnya sebagainya. Akan terasa lebih miris lagi ketika persoalan mafia peradilan diungkapkan pula secara gamblang. Dengan demikian, lengkaplah sudah penyakit kronis lembaga peradilan yang belum juga sembuh hingga saat ini. Proses mencari keadilan di suatu lembaga peradilan memiliki masalah mulai dari proses awal, tengah, akhir hingga pasca berakhirnya proses pencarian keadilan itu. Maka wajar jika sindiran seperti "lapor kambing, hilang sapi" begitu populer di telinga para aktivis peradilan. ${ }^{5}$ Dunia bisnis tentu tidak akan menerima model penyelesaian sengketa macam ini karena tidak sesuai dengan tuntutan perkembangannya, terlebih jika dibenturkan dengan popularitas dan reputrasi yang sedang digenggamnya sebagaimana telah disebutkan.

Jalur non litigasi (luar pengadilan) yang selanjutnya disebut sebagai jalur alternatif dalam penyelesaian suatu perkara (sengketa) tampak menjadi jawaban paling tepat dalam menyelesaikan persoalan yang ada sebagaimana telah disebutkan. Perbedaan karakter yang dimiliki oleh lembaga pengadilan dengan lembaga di luar pengadilan dalam menyelesaikan suatu perkara, menyebabkan hasil akhir yang dicapai pula bertolak belakang. Hasil akhir penyelesaian perkara

Indonesia, (Yogyakarta: Liberty), hal: 36. Yahya Harahap menyatakan bahwa dalam kenyataan praktik berbicara, sampai saat ini manusia di negara manapun, belum mampu menciptakan dan mendesain sistem peradilan yang efektif dan efisien. Karena ternyata, mendesain pengadilan yang seperti itu, tidak gampang. Banyaknya aspek yang saling bertabrakan plus beragamnya kepentingan yang harus dilindungi, tampak menjadi faktor utamanya. Padahal di sisi lain, untuk memenuhi luaran yang menjadi pokok keberadaan peradilan itu, menuntut sebuah sistem yang mampu melindungi kepentingan-kepentingan para pihak, sehingga tidak boleh berat sebelah dan tidak pula dibenarkan bentuk konspirasi sekecil apapun. M. Yahya Harahap(1997), Hukum Acara Perdata Tentang Gugatan, Persidangan, Penyitaan, Pembuktian, dan Putusan Pengadilan, (Jakarta: Sinar Grafika), hal: 229

5 Wirawan, Menyelesaikan Perdata secara Singkat, dalam http: //www.pikiranrakyat.com/cetak. Diakses pada tanggal 10 Januari 2008. Kritik dan hujatan terhadap lembaga peradilan hingga saat ini belum juga reda melihat realita penyelesaian perkara di dalamnya. Namun, di tengah kritikan dan hujatan itu, tidak berarti lembaga peradilan sudah tidak dieperlukan lagi keberadaannya, terlebih jika dibenturkan dengan kehadiran penyelesaian sengketa jalur alternative yang pula telah berkembang. Kritikan dan hujatan seharusnya lebih ditanggapi positif sebagai masukan bagi pihak pengadilan. Djoko Retnadi dalam http: //www.iei.or.id/publicationfiles/pdf. diakses pada tanggal 10 Januari 2008 
(konflik) antar masyarakat melalui jalur ini populer dengan sebutan win win solution. ${ }^{6}$ Selain itu, metode penyelesaian perkara di luar pengadilan (non litigasi) ini pada dasarnya juga telah mengakomodir secara sempurna berbagai tujuan sebagaimana yang dimiliki lembaga peradilan dalam menyelesaikan perkara. ${ }^{7}$

Konteksnya dalam bisnis islam (ekonomi syariah), terlepas dari rumusan fenomenal dengan menyatakan sengketa perekonomian syariah menjadi harus diselesaikan di Pengadilan Agama, penyelesaian sengketa jalur litigasi (Pengadilan Agama) ini dipandang juga telah tercoreng dengan berbagai kenyataan "miring" sebagaimana banyak terjadi di pengadilan lainnya. Hal ini akan lebih meyakinkan, ketika dikaitkan dengan kesiapan para hakim yang dipertanyakan dalam menyelesaikan sengketa ekonomi syariah itu. Oleh karenanya, Majelis Ulama Indonesia (MUI), menanggapi dengan munculnya Undang-Undang Nomor 3 tahun 2006 tentang Peradilan Agama, yang memasukkan ekonomi syariah sebagai salah satu kompetensi absolutnya, masih menjamin eksistensi Basyarnas sebagai penyelesai sengketa ekonomi syariah di luar pengadilan (non litigasi), meskipun masalah lain muncul pula mengikuti penerbitannya.

\section{Pengertian Arbitrase}

Dalam perspektif Islam, arbitrase dapat disepadankan dengan istilah tabkim. Tahkim sendiri adalah bahasa arab yang merupakan mashdar dari kata kerja hakkama. Secara etimologis, kata itu berarti menjadikan seseorang sebagai pencegah suatu sengketa. Pengertian tersebut erat kaitannya dengan pengertian menurut terminologisnya. ${ }^{8}$ Secara terminologi, tahkim dapat diartikan dengan bersandarnya dua orang yang bertikai (bersengketa) kepada seseorang yang mereka ridhoi keputusannya untuk menyelesaikan pertikaian mereka (para pihak). ${ }^{9}$

Selain kata arbitrase Islam yang dipadanankan dengan istilah tahkim, istilah yang menggambarkannya sebagai jalur penyelesaian sengketa perspektif Islam, Islam juga memperkenalkan lembaga penyelesaian sengketa para pihak yang disebut juga ash shulhu. Beberapa kata dalam bahasa Arab yang berkaitan dengan kata yang berakar pada kata sholuha ini antara lain; ashlaha, shillaha, tasholaha, as

${ }^{6}$ Win win solution adalah lawan dari win lose solution yang merupakan hasil akhir dari penyelesaian sengketa melalui jalur litigasi. Lebih lengkap baca dalam Suyud Margono, op.cit, hal: 23-28

7 Terdapat banyak hal yang menjadi kelebihan dari penyelesaian perkara melalui jalur non litigasi. Diantaranya, lebih menjamin perlakuan yang adil kepada para pihak, menyelesaikan sengketa, menjaga ketertiban umum, dan membawa nilai-nilai masyarakat yang terkandung dalam hokum untuk menyelesaikan sengketa. Lihat dalam Suyod Margono, ibid, hal: 24

${ }^{8}$ Suhrawardi K. Lubis (2000), Hukum Ekonomi Islam, (Jakarta: Sinar Grafika), hal: 186

${ }^{9}$ M. Abdul Fatah dalam Suhrawardi K. Lubis, Ibid 
Sufriadi: Memberdayakan Peran Badan Arbitrase Syariah Nasional ...

sulhu, as sholahiyah, as sholihu, ishlahun, ishlahiyah, mushlihun, dan mashlahah. Sholuha adalah bagus, baik (kebalikan dari buruk), ashlaha berarti memperbaiki, shollaha diartikan membereskan, shoolaha berarti berdamai dengan, tasholaha berarti berdamai atau saling berdamai, as sulhu berarti perdamaian, as sholahiyah berarti kepantasan, as sholihu berarti yang bagus, baik, ishlahun berarti perbaikan, koreksi, ishlahiyah berarti yang bermaksud, yang bersifat memperbaiki, mushlihun berarti pembaharu dari yang buruk atau juru damai, dan mashlahah dimaknai faidah, kepentingan, kemanfaatan dan kemaslahatan. As sulhu disejajarkan dengan as silmu, ishlah disejajarkan dengan diddul ifsad (lawan dari perusakan). ishlahun, silmun, dan sulhun dapat disejajarkan dengan makna satu yaitu perdamaian atau perbaikan. ${ }^{10}$ Dalam Al Mufid juga disebut bahwa as sulhu dan as silmu dapat disejajarkan dalam pengertian perdamaian. ${ }^{11}$

Lebih lanjut, kata itu diartikan dengan: berusaha menciptakan perdamaian; membawa keharmonisan; menganjurkan orang untuk berdamai antara satu dan yang lainnya; melakukan perbuatan baik; berperilaku sebagai orang suci (baik). Dikatakan, bahwa pengertian yang beragam itu berasal dari makna kata ini yang disebut dalam Al Qur'an. Adapun dalam bahasa Arab modern, istilah ini digunakan untuk pengertian pembaharuan. ${ }^{12}$ Sementara dalam pengertian syariat, ash shulhu berarti suatu akad (perjanjian) untuk mengakhiri perlawanan (sengketa) antara dua orang yang terlibat dalam sengketa. ${ }^{13}$

Sementara itu, dalam hukum positif, kajian-kajian tentang arbitrase umumnya dirujuk pada pendapat-pendapat para pakar hukum barat, dan jarang mengemukakan pemikiran pakar dari kalangan muslim secara proporsional. Padahal, dalam penyelesaian sengketa di masyarakat, Islam memiliki konsep yang jelas dan perbedaan subtantif dengan dasar yang berbeda, terutama dalam hal filosofinya. Lebih lanjut, konsep Islam tampak tidak kalah realistis untuk diterapkan di masyarakat modern dibanding dengan konsep yang banyak muncul dari barat.

Kata arbitrase sendiri berasal dari bahasa arbitrare (Latin), arbitrage (Belanda), arbitration (Inggris), schiedspruch (Jerman), arbitrage (Prancis), yang berarti kekuasaan untuk menyelesaikan sesuatu menurut kebijaksanaan atau damai oleh atbiter atau wasit. ${ }^{14} \mathrm{Hal}$ ini senada dengan apa yang disampaikan

${ }^{10}$ Adib Bisri dan Munawwir A Fatah (1999), Kamus Indonesia-Arab, Arab Indonesia, (Surabaya: Pustka Progresif), hal: 414-415

${ }^{11}$ Al Mufid, Kamus Arab Indonesia, Indoensia Arab, tt. CD

${ }^{12}$ Abdul Azis Dahlan, et.al, (2001), Ensiklopedi Hukum Islam, Jilid II, (Jakarta: PT Ichtiar Baru can Hoeve), hal: 740

${ }^{13}$ Abdul Qodir Audah (2000), At Tasyri' al jinai al Islam Muqoeonan bil Qonunil Wad'i, Juz Pertama, (Beirut: Muassash ar Risalah), hal: 773. Mengenai penyerapannya ke dalam bahasa Indonesia, lihat Abdul Azis Dahlan, et.al, (2001), Ensiklopedi Hukum Islam, Jilid II, (Jakarta: PT Ichtiar Baru can Hoeve), hal: 740

${ }_{14}$ Rahmadi Usman (2003), Pilihan Penyelesaian Sengketa di Luar Pengadilan, 
M. Husein dan A. Supriyani. ${ }^{15}$ Dikaitkannya istilah arbitrase dengan dengan kebijaksanaan seolah-olah memberi petunjuk bahwa majelis hakim arbitrase tidak perlu memerhatikan hukum dalam menyelesaikan sengketa para pihak, tetapi cukup mendasarkannya kepaa kebijaksanaan. Padangan tersebut keliru, karena arbiter juga menerapkan hukum seperti apa yang dilakukan oleh hakim di pengadilan. ${ }^{16}$ Atas dasar inilah, dalam beberapa literatur istilah arbitrase popular juga dengan istilah pengadilan swasta (karena keberadaannya adalah sendiri dan mandiri tanpa campur tangan institusi formal kenegaraan), pengadian pengusaha (karena pihak yang bersengketa di dalamnya banyak yang berlatarbelakang pengusaha), perwasitan (dalam kontek arbiternya), dan lain sebagainya.

Menurut Mertokusumo, arbitrase adalah suatu prosedur penyelesaian sengketa di luar pengadilan berdasarkan persetujuan para pihak yang berkepentingan untuk menyerahkan sengketa mereka kepada seorang wasit atau arbiter. ${ }^{17} \mathrm{Di}$ sini, wasit digunakan sebagai pihak ketiga yang netral dalam memutus perselisihan yang diajukan para pihak kepada arbiter. ${ }^{18}$

Sementara itu, pengertian arbitrase yang lebih rinci dikemukakan oleh Abdulkadir Muhammad. Ia mengatakan bahwa arbitrase adalah badan peradilan swasta di luar lingkungan peradilan umum, yang dikenal dengan khusus dalam dunia perusahaan. Arbitrase adalah peradilan yang dipilih dan ditentukan sendiri secara sukarela oleh pihak-pihak pengusaha yang bersengketa. Penyelesaian sengketa di luar pengadilan Negara merupakan kehendak bebas pihak-pihak. Kehendak bebas ini dapat dituangkan dalam perjanjian tertulis yang mereka buat sebelum atau sesudah terjadi sengketa sesuai dengan asas kebebasan berkontrak dalam hukum perusahaan. ${ }^{19}$

Adapun dalam Undang-Undang Nomor 30 Tahun 1999 disebutkan: Arbitrase adalah cara penyelesaian suatu sengketa perdata di luar peradilan umum yang didasarkan pada perjanjian arbitrase yang dibuat secara tertulis oleh para pihak yang bersengketa. ${ }^{20}$ Dari rumusan tersebut dapat disimpulkan bahwa sengketa yang dapat dibawa pada arbitrase adalah sengketa yang bersifat keperdataan. Para pihak telah menyepakati secara tertulis bahwa mereka, jika terjadi perkara mengenai perjanjian yang telah mereka buat, akan memilih penyelesaian sengketa melalui

(Bandung: PT. Citra Aditya Bakti), hal: 107

${ }^{15}$ M. Husein dan A. Supriyani dalam Joni Emirzon (2001), Alternatif Penyelesaian Sengketa di Luar Pengadilan (Negosiasi, Mediasi, Konsilisasi dan Arbitrase), (Jakarta: Gramedia Pustaka Utama), hal: 96

${ }^{16}$ Subekti (1981), Arbitrase Perdagangan, (Bandung: Penerbit Binacipta), hal: 1-3

${ }^{17}$ Sudikno Mertokusumo (1999), Mengenal Hukum: Suatu Pengantar, (Yogyakarta: Liberty), hal: 144

${ }_{18}$ Gatot Soemargono, (2006), Arbitrase dan Mediasi di Indonesia, (Jakarta: Gramedia Pustaka Utama), hal: 25

19 Abdulkadir Muhammad (1993), Pengantar Hukum Perusahaan Indonesia, (Bandung: PT. Citra Aditya Bakti), hal: 276

${ }^{20}$ Lihat pada pasal 1 butir 1 
Sufriadi: Memberdayakan Peran Badan Arbitrase Syariah Nasional ...

arbitrase dan tidak berperkara di depan peradilan umum. Dengan demikian, yang dilakukan adalah untuk memutuskan pilihan forum, yaitu yurisdiksi di mana suatu sengketa akan diperiksa, dan bukan pilihan hukum. ${ }^{21}$

\section{Dasar Hukum Arbitrase Syariah}

Penyelesaian perkara melalui musyawarah dengan artian bertemunya antara pihak yang bersengketa dalam satu majelis, pada dasarnya adalah jalur terbaik. Keuntungan yang didapatkan kedua pihak yang bersengketa (setidaknya) adalah penemuan solusi atau jalan keluar yang sama-sama disepakati. Hal ini sangat efektif meredam segala amarah yang ada dalam benak para pihak (terutama yang kalah) paska ditemukannya suatu solusi. Hal tersebut akan lebih sempurna jika jalur penyelesaian sengketa ini dikontekskan dengan fenomena yang terjadi di dunia modern. Banyaknya tuntutan terhadap seseorang, menjadikan keberadaan jalur penyelesaian semacam arbitrase (seharusnya) tumbuh subur.

Di Indonesia, terbentuknya lembaga arbitrase islam (Basyarnas) memiliki landasan hukum yang kuat, baik dari tinjauan hukum positif, terlebih dari hukum islam. Dalam Islam, penggambaran terhadap penyelesaian setiap sengketa yang terjadi di masyarakat, justru harus didahulukan. Sumber hukum yang mendasari keharusan menempuh jalur ini serta mengisyaratkan adanya suatu lembaga khusus menangani jalur ini, terdapat dalam Al Qur'an, As Sunnah dan Ijma' Ulama. Beberapa dasar itu adalah sebagai berikut.

"Dan kalau ada dua golongan dari mereka yang beriman itu berperang hendaklah kamu damaikan antara keduanya! Tapi kalau yang satu melanggar perjanjian terhadap yang lain, hendaklah yang melanggar perjanjian itu kamu perangi sampai surut kembali pada perintah Allah. Kalau dia telah surut, damaikanlah antara keduanya menurut keadilan, dan hendaklah kamu berlaku adil; sesungguhnya Allah mencintai orang-orang yang berlaku adil. Orang-orang beriman itu sesungguhnya bersaudara. Sebab itu damaikanlah (perbaikilah hubungan) antara kedua saudaramu itu dan takutlah terhadap Allah, supaya kamu mendapat rahmat" (QS. al Hujurat: 9-10)

"Dan jika kamu khawatir akan ada persengketaan antara keduanya (suami-isteri), maka kirimlah seorang hakam dari keluarga laki-laki dan seorang hakam dari keluarga perempuan. Dan jika kedua orang hakam itu bermaksud mengadakan perbaikan (perdamaian), niscaya Allah akan memberikan petunjuk kepada suami-isteri itu. Sesungguhnya Allah maha mengetahui lagi maha mengenal" (QS. An Nisa: 35)

Selain Al Qur'an, As Sunnah sebagai sumber hukum Islam kedua, juga memberikan penjelasan bagaimana suatu persengketaan harus segera didamaikan.

${ }^{21}$ Gatot Soemartono, op.cit, hal: 26 
Sufriadi: Memberdayakan Peran Badan Arbitrase Syariah Nasional ...

Diantaranya adalah sebagai berikut:

Dari Abi Hurairoh ra, mengabarkan bahwa Rasulullah saw bersabda: "ada seorang laki-laki membeli pekarangan dari seseorang. Orang yang membeli pekarangan tersebut menemukan sebuah guci yang berisikan emas. Si pembeli berkata, " ambillah emas yang ada pada saya, aku hanya membeli tanahnya saja daripadamu". Jawab penjual tanah, "aku telah menjual kepadamu tanah dan barang-barang yang terdapat di dalamnya". Kedua orang itu lalu bertahkim (mengangkat arbitrator kepada seseorang. Arbitrator berkata, "apakah kamu berdua mempunyai anak?”. Salah seorang yang bersengketa menjawab, "ya. Saya mempunyai seorang anak laki-laki". Dan, yang lai nmenjawab, "saya mempunyai seorang anak perempuan". Lalu arbitrator berkata, kawinkanlah anak laki-laki itu dengan anak perempuan itu dan biayailah kedua mempelai dengan emas itu". Dan kedua orang tersebut menyedekahkan (sisanya kepada fakir miskin)". (HR. Bukhari Muslim) ${ }^{22}$

Adapun ijma' ulama sebagai sumber hukum Islam ketiga juga telah memperkuat keberadaan lembaga arbitrase untuk mengantisipasi persengketaan dalam berbagai aspek kehidupan. Penyelesaian sengketa dengan arbitrase setelah Rasulullah wafat, banyak dilakukan pada masa sahabat dan ulama setelahnya. Penyelesaian sengketa dengan cara mendamaikan para pihak melalui musyawarah dan kesepakatan bersama, sempat menjadi yurisprudensi hukum Islam dalam beberapa kasus. Keberadaan ijma' sahabat atau ulama sangat dihargai dan tidak ada yang menentangnya. Dalam hal ini, Umar bin Khottob pernah mengatakan, "tolaklah permusuhan hingga mereka berdamai, karena pemutusan perkara melalui pengadilan akan mengembangkan kedengkian di antara mereka."

Dalam konteks keindonesiaan, perkara ijma' ulama ini banyak diprakarsai oleh Majelis Ulama Indonesia (MUI). Pembentukan Badan Arbitrase Muamalat Indonesia (BAMUI) adalah salah satu yang dapat dikatakan masuk dalam kategori ijma' ulama. Walaupun BAMUI dibentuk dan disetujui hanya oleh sebagian Ulama atau cendikiawan muslim, secara yuridis formal dan dari segi hukum Islam mempunyai kekuatan hukum yang tetap. Terlebih, keberadaan lembaga semacam ini memang telah menjadi sebuah tuntutan seiring berkembangnya perekonomian dengan sistem syariah di Indonesia. ${ }^{23}$

Jika diamati lebih lanjut, ketiga sumber hukum Islam ini, dalam hal penyelesaian sengketa jalur alternatif ash shulhu (ishlah) atau tahkim, sesungguhnya mengisyaratkan tidak terbatas hanya pada persoalan bisnis (ekonomi) atau keperdataan lainnya, melainkan juga dapat dipraktekkan dalam penyelesaian kasus di bidang perang, politik, pidana, dan lain sebagainya. Bahkan penyelesaian

${ }^{22}$ Fathurrahman (1977), Hadist-Hadist Tentang Peradilan Agama, (Jakarta: Bulan Bintang, hal: 209

${ }^{23}$ Baca lebih lengkap dalam Rahmat Rosyadi dan Ngatino (2002), Arbitrase dalam Perspektif Islam dan Hukum Positif, (Bandung: PT. Citra Aditya Bakti), hal: 48-49 
Sufriadi: Memberdayakan Peran Badan Arbitrase Syariah Nasional ...

ini (harus) lebih diutamakan. Asumsi yang berkembang di benak masyarakat secara umum, bahwa penyelesaian sengketa melalui badan peradilan dipastikan bersifat antagonistis dan selalu menimbulkan kedengkian di antara umat Islam. Kedengkian itu muncul akibat dari keterpaksaan menerima putusan dari pihak pengadilan, baik memenuhi rasa keadilan atau tidak.

Selanjutnya, keberadaan Basyarnas secara yuridis formal mempunyai legitimasi yang kuat di Indonesia. Terdapat dasar hukum yang memungkinkan lembaga lain di luar lembaga peradilan umum dapat menjadi wasit/hakim dalam penyelesaian sengketa para pihak. Walaupun, penyelenggaraan kekuasaan kehakiman pada dasarnya diserahkan pada badan peradilan yang (saat itu) berpedoman pada UU No. 14 Tahun 1970 tentang Ketentuan-Ketentuan Pokok Kehakiman. Meskipun dalam Pasal 3 ayat (2) UU tersebut dinyatakan bahwa hanya badan peradilan negara yang menetapkan dan menegakan hukum di Indonesia. Akan tetapi, dalam penjelasan pasal itu membolehkan penyelesaian sengketa di luar pengadilan. Pada kalimat berikutnya, penjelasan Pasal 3 menyatakan bahwa penyelesaian perkara di luar pengadilan atas dasar perdamaian atau melalui wasit (arbitrase) tetap diperbolehkan. Hanyasaja, putusan arbitrase akan mempunyai kekuatan eksekutorial (executoir) setelah didaftarkan di lembaga peradilan. ${ }^{24}$

Ketentuan Arbitrase sebagaimana dalam pasal 615 sampai dengan pasal 651 Reglemen Acara Perdata (Reglement op de Rechtvordering, Staatblaad 1847: 52), Pasal 377 Reglement Indonesia yang Diperbaharui (Het Herziene Indonesisch Reglement Staadblad 1941: 44), dan Reglement Acara untuk Daerah Luar Jawa dan Madura (Reglement Buitengsewesten, staatsblad 1927: 227), dinyatakan sudah tidak berlaku sejak diterbitkannya Undang-Undang Nomor 30 Tahun 1999 Tentang Arbitrase dan Alternatif Penyelesaian Sengketa. ${ }^{25}$ Undang-Undang ini adalah aturan pokok bagi setiap lembaga arbitrase di indonesia, seperti Badan Arbitrase Nasional Indonesia (BANI), Badan Arbitrase Pasar Modal Indonesia (BAPMI) dan Badan Arbitrase Syariah Nasional (Basyarnas) sendiri.

Dengan demikian, aturan paling tepat yang mendasari pembentukan dan operasional Basyarnas adalah penjelasan UU Kekuasaan Kehakiman dan UU Arbitrase dan APS. Khusus yang terakhir, belakangan menimbulkan perdebatan setelah UU Nomor 3 tahun 2006 tentang Pengadilan Agama diterbitkan. Terdapat pakar yang mengemukakan pendapatnya dengan kesan mencukupkan aturan yang dipakai Basyarnas sebatas aturan ini saja. ${ }^{26}$ Namun, di pihak lain menentang aturan yang tidak spesifik mengatur tentang Basyarnas, terutama mengenai operasional dan langkah lebih lanjut setelah klausa arbitrase dihasilkan, sehingga

${ }^{24}$ Suyud Margono, Op. cit, hlm 115

25 Pasal 81 Undang-Undang Nomor 30 Tahun 1999.

26 Pendapat semacam ini contohnya seperti yang diungkapkan oleh Rahmad Rosyadi dan Ngatino bahwa landasan yang dimiliki BAMUI (badan arbitrase syariah sebelum Basyarnas) telah memiliki dasar dan operasional yang kuat untuk tetap eksis. Lebih jelas baca dalam Rahmad Rosyadi dan Ngatino, op.cit, hal: 125-126 
cenderung mendesak agar pengaturan spesifik mengenai Basyarnas secepatnya diwujudkan dalam bentuk Undang-Undang. Alasannya, antara Basyarnas yang menerapkan konsepsi syariah dalam menyelesaikan urusan yang berbasis syariah berbeda secara filososfis dengan aturan yang ada dalam Undang-Undang Arbitrase dan ADR yang tidak mengakomodir nilai filosofis tersebut secara sempurna. ${ }^{27}$

\section{Realita Kinerja Basyarnas dan Problematikanya}

Jika dirujuk jauh ke belakang, munculnya lembaga arbitrase di dunia lebih identik dengan dua hal. Pertama, hanculnya idealitas lembaga peradilan sebagai penyelesai sengketa (perkara) di masyarakat, terutama penguasaha. Berbagai dampak negatif kemudian sangat terasa bagi para pihak dalam penyelesaian perkara tersebut melalui lembaga peradilan. Padahal, lembaga peradilan sendiri pada dasarnya adalah tempat mengadu mereka yang merasa dirugikan dan menuntut keadilan dari hak yang dirampas darinya. Hal ini menyebabkan munculnya keraguan masyarakat, khususnya para pelaku bisnis. Kedua, realitas perkara di pengadilan juga menunjukkan "ketidakmampuan" bekerja secara maksimal karena menumpuknya perkara masuk dan tidak dapat terselesaikan dengan baik. Di samping itu, kompetensi yang dimiliki hakim yang tidak menguasai segala bidang secara mendalam juga menjadi masalah kronis hingga kini. Pertimbangan pertama tampak lebih menunjukkan bahwa keberadaan lembaga peradilan adalah sebuah kebutuhan masyarakat sendiri. Sedangkan kedua mengisyaratkan bahwa arbitrase dalam segala bentuknya, adalah kebutuhan daripada lembaga peradilan. ${ }^{28}$

Selain mengharapkan penyelesaian sengketa dengan landasan syariah, hal diatas tampak menjadi pertimbangan lagis dalam pembentukan dan mempertahankan eksistensi Basyarnas sebagai penyelesai sengketa. Keberadaan Basyarnas saat ini (atau bahkan jauh sebelum ini) dan saat yang akan datang,

${ }^{27}$ Baca ungkapan Hanawijaya dalam http: //www.hukumonline.com, diakses tanggal 15 Januari 2008. Bandingkan Peri Umar Farouk, dalam http: //www.wikidot. com diakses tanggal 15 Januari 2008

${ }^{28}$ Tidak mudah menciptakan suatu sistem penyelesaian sengketa yang diinginkan dunia bisnis. Dunia bisnis menghendaki sistem yang tidak formal dan pemecahan masalah menuju masa depan. Paradigma sistem seperti ini sulit diatur dalam sistem litigasi (ordinary court) karena sistem litigasi bukan didesain untuk menyelesaikan masalahm melainkan lebih mengutamakan penyelesaian yang berlandaskan penegakan dan kepastian hukum. Bahkan, jika dilihat secara mendalam, penyelesaian sengketa yang lebih tepat untuk masyarakat indonesia adalah penyelesaian dengan jalur alternatif. Jalur alternatiflah yang metode penyelesaian yang sesuai dengan jiwa masyarakat indonesia. Baca lebih lanjut dalam Suyud Margono, log.cit, hal: 138-140. Sejauh ini, arbitrase adalah lembaga yang paling banyak digunakan oleh para pengusaha atau pebisnis. Bahkan sejarah awal munculnya pengadilan arbitrase juga untuk menyelesaikan sengketa para pengusaha. Rahmad Rosyadi dan Ngatino, log.cit, hal: 91 
sangat dibutuhkan aktifitas kerja dan efektifitas kinerjanya. Hal itu disebabkan karena keberlanjutan perkembangan ekonomi syariah ke depan tampaknya tidak dapat diragukan. Beberapa analisis ekonom dan pelaku bisnis menyatakan keyakinannya terhadap keberlanjutan perekonomia syariah.

Namun, keberadaan Basyarnas di tengah-tengah masyarakat, realita justru mempertontonkan sebaliknya. Data menunjukkan bahwa dari awal berdirinya (2003) hingga sekarang (2007), baru dua sengketa perbankan syariah yang berhasil dituntaskan Basyarnas. Tiga sengketa lainnya sempat didaftarkan tetapi akhirnya tidak diproses lantaran kurang memenuhi persyaratan. Sementara BAMUI, dari 1993 hingga 2003 tercatat menyelesaikan 12 sengketa perbankan syariah. Dengan demikian, Basyarnas plus BAMUI baru menyelesaikan 14 sengketa perbankan syariah. ${ }^{29}$ Terlepas dari berbagai asumsi, hipotesis, atau prasangka baik terhadap keberadaan basyarnas dan perilaku islami ${ }^{30}$ yang diterapkan semua pihak dalam bertransaksi ekonomi islam, sejak kelahiran Basyarnas hingga kini, berbagai problem terlihat masih "betah" menghuni tubuh Basyarnas. Salah satu problem substantif dan urgen dipecahkan adalah mengenai regulasi penyelesaia sengketa melalui Basyarnas.

Sampai saat ini, aturan yang dijalankan Basyarnas, baik secara konseptual dan implementasi, sepenuhnya masih merujuk kepada UU Nomor 30 tahun 1999 tentang Arbitrase dan Alternatif Penyelesaian Sengketa. Undang-undang ini adalah pokok penerapan semua lembaga arbitrase di indonesia. Hanya, perumusan aturan ini sesungguhnya dominan dilatarbelakangi perkembangan bisnis (ekonomi) konvensional yang banyak menimbulkan sengketa. Dengan demikian, muatan-muatan yang mengarah pada pertumbuhan ekonomi syariah, khususnya Basyarnas sebagai penyelesai sengketa terlihat tidak begitu diakomodir. Akibatnya, terdapat berbagai persolan muncul, yang paling heboh adalah kewajiban Basyarnas mendaftarkan putusan arbitrase ke pengadilan negeri. ${ }^{31}$ Sejak awal, dipahami bahwa landasan yang digunakan ekonomi syariah dan konvensional memiliki perbedaan yang substansi, sehingga penyelesaian sengketa antara keduanya juga memiliki perbedaan. Dengan demikian, Pengadilan Negeri yang populer (dalam perkara perdata) menangani ekonomi konvensional sejatinya tidak dapat memproses sengketa ekonomi syariah yang memiliki perbedaan prinsip dengan ekonomi konvensional. Sementara itu, Pengadilan Agama yang diasumsikan lebih tepat menangani persolan ini, secara normatif, tidak berhak menanganinya

${ }^{29} \mathrm{http}$ : //www.hukumonline.com diakses tanggal 15 Januari 2008

${ }^{30}$ Dalam sebuah wawancara, Ketua Basyarnas, Yudo Pramono, menghimbau agar berbaiksangka dalam menanggapi realita sedikitnya sengketa yang masuk ke Basyarnas. Dia menyatakan: "Melihat sedikitnya sengketa yang masuk Basyarnas kita punya prasangka baik atau asumsi bahwa sengketa itu sedikit di perbankan syariah oleh karena ada mekanisme internal sendiri disamping barangkali kesadaran masing-masing pihak untuk melaksanakan syariah". Baca dalam http: //www.pmii-ciputat.org

${ }^{31}$ Lihat dalam pasal 59 UU Arbitrase dan Alternatif Penyelesaian Sengketa 
karena tidak masuk dalam kompetensi absolutnya. Suasana dilematis ini terus berlangsung dalam lingkaran perasaan canggung bagi pihak Basyarnas, hanya saja tidak diekspos berlebihan dengan banyak pertimbangan.

Adapun sekarang, ketika UU Pengadilan Agama tahun 2006 diterbitkan, tidak tuntas menyelesaikan problem lama Basyarnas, sebaliknya cenderung menimbulkan polemik baru dalam pengaturan operasional Basyarnas. ${ }^{32}$ Perdebatan para pakar hukum tidak dapat terelakkan. Bahkan yang menjadi "target" pembicaraan tidak hanya posisi Basyarnas sendiri, melainkan UU itu yang dinilai berbenturan dengan UU Arbitrase dan APS.

Dalam kondisi seperti ini, keterpurukan Basyarnas jelas akan lebih menjadijadi, setidaknya, perkara yang masuk ke meja Basyarnas akan jauh berkurang. Karena problem tidak hanya terjadi di wilayah akademis, tapi juga akan merambah ke ranah bisnis. Polemik semacam ini akan menjadi pertimbangan serius bagi pebisnis untuk menyelesaikan sengketanya di Basyarnas. Keragu-raguan akan muncul dan pada akhirnya akan mengakumulasi keyakinan pebisnis itu untuk memandang sebelah mata terhadap Basyarnas dalam menyelesaikan sengketanya. Maka, di sini kemudian letak perlunya kejelasan regulasi bagi Basyarnas sebagai lembaga arbitrase penyelesai sengketa ekonomi syariah.

\section{Urgensi Pengaturan Basyarnas dalam Tata Hukum Nasional}

Berbagai studi tentang hubungan hukum dan pembangunan ekonomi menunjukkan bahwa pembangunan ekonomi tidak akan berhasil tanpa pembaharuan hukum. Memperkuat institusi-institusi hukum adalah precondition for economic change, crucial to the viability of new political system, dan an agent of social change. ${ }^{33}$

Agar hukum dapat berperan dalam pembangunan ekonomi nasional maka hukum di Indonesia harus memenuhi lima kualitas, yaitu; kepastian (predictability); stabilitas (stability); keadilan (fairness); pendidikan (education); dan kemampuan SDM di bidang hukum (special abilities of the lawyer). ${ }^{34}$ Kelima

${ }^{32}$ Pasal 49 adalah pokok munculnya persoalan. Dalam uu tersebut, penambahan kompetensi absolut PA dengan penyelesaian sengketa ekonomi syariah ditanggapi banyak pakar. Sebagian menyatakan bahwa pasal ini tidak dapat berlaku karena bertentangan dengan UU Arbitrase dan APS, dan sebagian lain menyatakan bahwa UU PA tahun 2006 adalah aturan khusus (lex spesialis) dari aturan sebelumnya (lex generalis). Yang lebih parah, terdapat anggapan yang menyatkan bahwa dengan terbitnya UU ini, maka praktis peran Basyarnas dapat dikatakan betul-betul pudar, karena telah digantikan oleh PA.

33 Agustianto, Politik Hukum Ekonomi Syariah, baca dalam http: //www. karimconsulting.com diakses tanggal 15 Januari 2008

${ }^{34}$ Penjelasan lebih lengkap, baca dalam Agustiano, Ibid 
Sufriadi: Memberdayakan Peran Badan Arbitrase Syariah Nasional ...

fungsi regulasi ini merupakan modal dalam membuat aturan hukum yang efektif dalam membangun objek yang diatur.

Sejauh ini, paska penerbitan dan perdebatan mengenai materi UU PA tahun 2006, pembicaraan seputar Basyarnas terlihat mengarah pada tuntutan pengaturan ulang Basyarnas. ${ }^{35}$ Dari sisi hukum, ini adalah tuntutan yang tepat untuk terus dilakukan. Mempertimbangkan fenomena yang terjadi, sejauh ini, pengaturan tentang "keberadaan" lembaga arbitrase sebagai penyelesai sengketa telah memiliki regulasi yang jelas dan kuat. Namun, khusus Basyarnas, ini tidak cukup. Aturan-aturan yang telah ada justeru harus ditinjau ulang dan diperbaiki sesuai dengan tuntutan terhadap Basyarnas ke depan. Karena dengan pengaturan demikianlah, tanggung jawab Basyarnas sebagai sebuah lembaga yang dapat menyelesaikan sengketa ekonomi syariah, dapat tergambar dengan jelas dan dapat terwujud sebagaimana diharapkan.

\section{Penutup}

Selama ini, ketidakefektifan kinerja Basyarnas disebabkan banyak hal. Selain faktor internal seperti stok dana operasional yang sangat minim, pengurus Basyarnas yang kurang intens, dan lain sebagainya, ketidakefektifan itu juga sangat dipengaruhi oleh aturan yang tidak memihak kepada Basyarnas. Pengaturan terhadap Basyarnas harus digagas dan diterbitkan ulang oleh yang memiliki wewenang.

Perjuangan terhadap penerapan syariah ala indonesia ke depan harus dilakukan secara menyeluruh. Sejarah membuktikan bahwa penerapan suatu lembaga dalam skala nasional tidak akan berkembang sebagaimana harapan jika tidak didorong dengan regulasi. Basyarnas adalah salah satu perangkat yang seharusnya berperan banyak dalam mendukung perkembangan ekonomi syariah indonesia. Tantangan ekonomi syariah ke depan lebih besar, sehingga semua langkah konstruktif dan antisipatif harus digagas dan dilakukan sejak dini. Wallahu a'lam bi kulli umur.

\section{DAFTAR PUSTAKA}

Abdul Azis Dahlan, et.al, (2001), Ensiklopedi Hukum Islam, Jilid II, Jakarta: PT Ichtiar Baru can Hoeve.

${ }^{35}$ MA kini mulai menggodok Kompilasi Hukum Ekonomi Syariah (KHES). Dalam penggodakan itu, MA sepatutnya memperhatikan persoalan ini dengan serius. Melalui KHES nantinya harus benar-benar menegaskan bagaimana idealnya penyelesaian sengketa yang timbul dalam praktik ekonomi syariah. Selain itu, MA juga tentunya tidak boleh memandang sebelah mata fatwa-fatwa yang dihasilkan DSN. Pun, MA tak patut mengabaikan pasal 49 UU No. 3 tahun 2006. http: //www.hukumonline.com diakses tanggal 15 Januari 2008 
Sufriadi: Memberdayakan Peran Badan Arbitrase Syariah Nasional ...

Abdulkadir Muhammad (1993), Pengantar Hukum Perusahaan Indonesia, Bandung: PT. Citra Aditya Bakti.

Abdul Qodir Audah (2000), At Tasyri' al jinai al Islam Muqoeonan bil Qonunil Wad'i, Juz Pertama, Beirut: Muassash ar Risalah.

Adib Bisri dan Munawwir A Fatah (1999), Kamus Indonesia-Arab, Arab Indonesia, Surabaya: Pustka Progresif.

Fathurrahman (1977), Hadist-Hadist Tentang Peradilan Agama, Jakarta: Bulan Bintang.

Gatot Soemartono (2006), Arbitrase dan Mediasi di Indonesia, Jakarta: Gramedia Pustaka Utama.

Ibnu Hajar Astqolani (1994), Bulughul Maram dan Terjemahnya (alih bahasa: Masdar Helmy), Bandung: Gema Risalah Press.

M. Husein dan A. Supriyani dalam Joni Emirzon (2001), Alternatif Penyelesaian Sengketa di Luar Pengadilan: Negosiasi, Mediasi, Konsilisasi dan Arbitrase, Jakarta: Gramedia Pustaka Utama.

M. Yahya Harahap (1997), Beberapa Tinjauan Mengenai Sistem Peradilan dan Penyelesaian Sengketa, Jakarta: Sinar Grafika.

(1997), Hukum Acara Perdata Tentang Gugatan, Persidangan, Penyitaan, Pembuktian, dan Putusan Pengadilan, Jakarta: Sinar Grafika.

Nur Kholis (2006), Penegakan Syariah Islam di Indonesia (Perspektif Ekonomi), Jurnal Hukum Islam Al Mawarid, Edisi: XVI, Fakultas Ilmu Agama Islam, UII: Yogyakarta.

Rahmadi Usman (2003), Pilihan Penyelesaian Sengketa di Luar Pengadilan, Bandung: PT. Citra Aditya Bakti.

Rahmat Rosyadi dan Ngatino (2002), Arbitrase dalam Perspektif Islam dan Hukum Positif, Bandung: PT. Citra Aditya Bakti.

Suyud Margono (2004), Alternative Dispute Resulotion (ADR) dan Arbitrase, Bogor: Ghalia Indonesia.

Sudikno Mertokusumo (1998), Hukum Acara Perdata Indonesia, Yogyakarta: Liberty.

Suhrawardi K. Lubis (2000), Hukum Ekonomi Islam, Jakarta: Sinar Grafika.

Subekti (1981), Arbitrase Perdagangan, Bandung: Penerbit Binacipta.

Sudikno Mertokusumo (1999), Mengenal Hukum: Suatu Pengantar, Yogyakarta: Liberty.

Tim Penyusun Kamus Pusat Pembianaan dan Pengembangan Bahasa (1990), Kamus Besar Bahasa Indonesia, (Jakarta: Balai Pustaka).

Dadang Muljawan (2007), Islamic Financial Engineering; A Regulatory Perspective, Slide yang disampaikan pada International Seminar on Islamic Financial Engineering 9-10 January, Yogyakarta, Indonesia

Agustianto, Politik Hukum Ekonomi Syariah, dalam http: //www.karimconsulting. 
Sufriadi: Memberdayakan Peran Badan Arbitrase Syariah Nasional ...

com diakses tanggal 15 Januari 2008.

Al Mufid, Kamus Arab Indonesia, Indoensia Arab, tt. CD.

Djoko Retnadi dalam http: //www.iei.or.id/publicationfiles/pdf. diakses pada tanggal 10 Januari 2008.

http: //www.bi.go.id diakses tanggal 25 Desember 2007.

http: //www.pmii-ciputat.org diakses tanggal 15 Januari 2008.

http: //www.hukumonline.com diakses tanggal 15 Januari 2008.

Peri Umar Farouk, Kelembagaan, Operasional \& Pengembangan Produk Bank Syariah: Perspektif Hukum Positif, dalam http: //www.wikidot.com diakses tanggal 15 Januari 2008.

Wirawan, Menyelesaikan Perdata secara Singkat, dalam http: //www.pikiran-rakyat. com/cetak. Diakses pada tanggal 10 Januari 2008 